\title{
A Concise Total Synthesis of $(R)$-Fluoxetine, a Potent and Selective Serotonin Reuptake Inhibitor
}

\author{
Ângelo de Fátima, Alexandre Augusto M. Lapis and Ronaldo A. Pilli \\ Instituto de Química, Universidade Estadual de Campinas, CP 6154, 13084-971, Campinas - SP, Brazil \\ $(R)$-Fluoxetina, um inibidor potente e seletivo da recaptação da serotonina, foi sintetizada em seis \\ etapas, $50 \%$ de rendimento total e $99 \%$ de excesso enantiomérico a partir do benzaldeído via alilação \\ catalítica assimétrica empregando-se o sistema catalítico desenvolvido por Maruoka e colaboradores. \\ $(R)$-Fluoxetine, potent and selective serotonin reuptake inhibitor, has been synthesized in six \\ steps, $50 \%$ overall yield and $99 \%$ ee from benzaldehyde via catalytic asymmetric allylation with \\ Maruoka's catalyst.
}

Keywords: fluoxetine, serotonin reuptake inhibitor, catalytic asymmetric allylation

\section{Introduction}

The anti-depressants drugs with a 3-aryloxy-3-phenylpropylamine sub-structure (for example, fluoxetine, atomoxetine and nisoxetine) are among the most important pharmaceuticals for the treatment of psychiatric disorders and metabolic problems. ${ }^{1,2}$ In addition, several members of this class have shown promise for the treatment of alcoholism, chronic pain and eating disorders such as obesity and bulimia. ${ }^{3-5}$

Fluoxetine (1) (Figure 1), a selective serotonin reuptake inhibitor (SSRI), is widely used in clinical practice for the treatment of depression. In fact, the selective serotonin reuptake inhibitors, and particularly fluoxetine (1), have become first line drugs in the pharmacotherapy of patients with depression, whereas tricyclic antidepressants are now considered as second-line agents. This is because the drug possesses tolerability and safety advantages over the tricyclic agents. ${ }^{6-8}$ In experimental models of<smiles>CNCCC(Oc1ccc(C(F)(F)F)cc1)c1ccccc1</smiles>

Fluoxetine (1)

Figure 1. Structure of fluoxetine (1).

* e-mail: pilli@iqm.unicamp.br inflammation, fluoxetine (1) has been shown to exert antiinflammatory and pain relieving effects. ${ }^{9-12}$ Fluoxetine (1) [trade name Prozac $^{\circledR}$ ] is currently marketed in its racemic form, despite studies showing that the two enantiomers have different activities and rates of metabolization. ${ }^{3,4}$

Due to its pharmaceutical importance and to the different pharmacological profiles of the individual enantiomers, the development of new strategies for preparing optically pure fluoxetine (1) has received growing interest in recent years. ${ }^{13}$ Several methods of enantioselective synthesis of both enantiomers of fluoxetine (1) have been reported and chirality has been introduced via enantioselective hydroxylation, ${ }^{14}$ enantioselective epoxidation followed by selective epoxide opening, ${ }^{15-17}$ chemical $^{18-23}$ and enzymatic ${ }^{24-28}$ reduction of ketones and $\beta$-ketoesters, stereoselective coupling reaction using chiral auxiliary or chiral catalyst, ${ }^{29,30}$ as well as enzymatic ${ }^{31,32}$ or chemical ${ }^{33,34}$ resolution of benzylic alcohols.

Among the strategies developed for enantiomerically pure $(R)$-fluoxetine $[(R)-\mathbf{1}]$, Miles and co-workers described the $\mathrm{Ti}(\mathrm{O} \mathrm{Pr})_{4} /(R)-\mathrm{BINOL}$ asymmetric ene reaction of 3methylene-2,3-dihydrofuran (prepared in 63\% yield from 3-furaldehyde as a 3.5:1 mixture with 3-methylfuran) with benzaldehyde which afforded $(R)$-fluoxetine hydrochloride $[(R)-1 . \mathrm{HCl}]$ in 6 steps, $56 \%$ overall yield and $>97 \%$ ee from 3 -furaldehyde. ${ }^{30}$ Recently, Shibasaki and coworkers carried out the total synthesis of $(R)$ fluoxetine (1) in a multigram scale (4 steps, $67 \%$ overall yield, $99 \%$ ee) via the catalytic asymmetric epoxidation 
of $N$-methyl-trans-cinnamamide, followed by regioselective epoxide opening. ${ }^{16}$

The development of chiral Lewis acids or bases for the enantioselective catalytic reactions is one of the most important recent advances in asymmetric synthesis. ${ }^{35,36}$ Enantioselective catalytic allylation (ECA) is one of the powerful $\mathrm{C}-\mathrm{C}$ bond-forming reactions that have attracted considerable attention in asymmetric synthesis. ${ }^{37}$ In our recent studies, we have employed ECA for the highly stereoselective synthesis of $(R)$-argentilactone and $(R)$ goniothalamin from the propargylic aldehyde 2-octinal and $(E)$-cinnamaldehyde, respectively. ${ }^{38-40}$ Here, we describe a short and high-yielding enantioselective total synthesis of fluoxetine hydrochloride $[(R)-\mathbf{1} \cdot \mathrm{HCl}]$ from benzaldehyde featuring its enantioselective asymmetric allylation with the $\mathrm{Ti}(\mathrm{IV}) /(R)$-BINOL-based catalyst developed by Maruoka and coworkers as the key step. ${ }^{41}$

\section{Results and Discussion}

Our approach to the synthesis of fluoxetine hydrochloride $[(R)-\mathbf{1} \cdot \mathrm{HCl}]$ centered on the treatment of benzaldehyde (2) with the in situ generated chiral catalyst $(R, R)$-A (Figure 2$)^{41}$ in $\mathrm{CH}_{2} \mathrm{Cl}_{2}$ at $-20^{\circ} \mathrm{C}$ for $36 \mathrm{~h}$, followed by the addition of allyltri- $n$-butyltin to provide homoallylic alcohol $(R)$-1-phenyl-but-3-en-1-ol (3) in $90 \%$ yield $\left\{[\alpha]_{\mathrm{D}}+53^{\circ}(c=1.1\right.$, benzene $)$, lit. $^{42}[\mathrm{a}]_{\mathrm{D}}-50.5^{\circ}(c=1.1$, benzene) for $(S)$-isomer, $96 \%$ ee (Scheme 2). The enantiomeric purity of $\mathbf{3}$ was determined to be $>99 \%$ ee by chiral HPLC analysis [Chiralcel OD column; Hex: $\mathrm{PrOH}$, 98:2, flow rate $=1 \mathrm{~mL} \mathrm{~min}^{-1}, \lambda_{\text {max. }}=257 \mathrm{~cm}^{-1}, \mathrm{t}_{\mathrm{R}}=11.8 \mathrm{~min}$ for $(S)$-isomer, $\mathrm{t}_{\mathrm{R}}=17.2 \min$ for $(R)$-isomer].

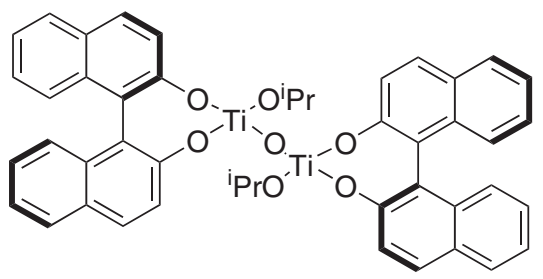

$(R, R)-\mathbf{A}$

Figure 2. The $\mu$-oxo bis(binaphthoxy)(isopropoxy)titanium complex $(R, R)$-A developed by Maruoka and coworkers. ${ }^{41}$

The conversion of $\mathbf{3}$ to $(R)$-1-phenyl-1,3-propanediol (4) $\left\{[\alpha]_{\mathrm{D}}+66^{\circ}\left(c=2.4, \mathrm{CH}_{2} \mathrm{Cl}_{2}\right)\right.$, lit. $^{32}[\alpha]_{\mathrm{D}}+65^{\circ}(c=2.4$, $\left.\left.\mathrm{CH}_{2} \mathrm{Cl}_{2}\right)\right\}$ was carried out by oxidative cleavage according to the Lemieux-Johnson protocol, ${ }^{43}$ followed by $\mathrm{NaBH}_{4}$ reduction of the crude aldehyde (87\% overall yield). The secondary amino functionality was introduced next via the corresponding mesylate $\mathbf{5}$ which was regioselectively prepared in $85 \%$ yield via treatment of diol 4 with mesyl chloride (1.0 equiv.) and $\mathrm{Et}_{3} \mathrm{~N}$ at $0{ }^{\circ} \mathrm{C}$. However, for preparative purposes mesylate $\mathbf{5}$ was used in the next step without further purification as it proved to be rather unstable to chromatography on silica gel and storage. It was straightforwardly converted to $(R)-N$-methyl-3-phenyl3-hydroxypropylamine (6) in $96 \%$ yield upon treatment with aqueous methylamine under reflux. ${ }^{15}$ The total synthesis of $(R)$-fluoxetine $[(R)-\mathbf{1}$.HCl] was concluded after nucleophilic aromatic substitution with 4-chlorobenzotrifluoride by heating it with the sodium salt of alcohol 6 in DMSO at 80-100 ${ }^{\circ} \mathrm{C}$. Acidification with $\mathrm{HCl}(\mathrm{g})$ in ethyl ether led to the $(R)$-fluoxetine hydrochloride $[(R)$ 1.HCl $]\left\{[\alpha]_{\mathrm{D}}-14^{\circ}\left(c=1, \mathrm{CHCl}_{3}\right)\right.$, lit. $^{23}[\alpha]_{\mathrm{D}}-13.8^{\circ}(c=1$, $\left.\mathrm{CHCl}_{3}\right)$ \} in $78 \%$ yield (Scheme 1).<smiles>O=Cc1ccccc1</smiles><smiles>COCC[C@H](O)c1ccccc1</smiles>

5

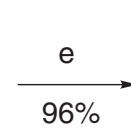

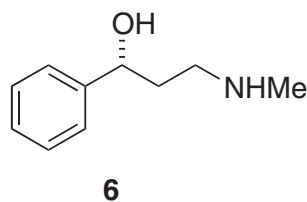

6<smiles>CNCC[C@@H](Oc1ccc(C(F)(F)F)cc1)c1ccccc1</smiles>

(R)-Fluoxetine hydrochloride

$[(R)-1 . \mathrm{HCl}](1)$

Scheme 1. Reagents and conditions: a) $(R, R)-\mathbf{A}\left\{\mathrm{TiCl}_{4}(5 \mathrm{~mol} \%), \mathrm{Ti}\left(\mathrm{O}^{\mathrm{i} P r}\right)_{4}(15 \mathrm{~mol} \%), \mathrm{Ag}_{2} \mathrm{O}(10 \mathrm{~mol} \%),(R)-\mathrm{BINOL}(20 \mathrm{~mol} \%)\right\}$, allyl- $n-$ tributyltin, $\mathrm{CH}_{2} \mathrm{Cl}_{2}, 0{ }^{\circ} \mathrm{C}, 72 \mathrm{~h}\left(90 \%, 99 \%\right.$ ee); b) $\mathrm{OsO}_{4}, \mathrm{NaIO}_{4}$, ethyl ether: water (1:1, v/v), 2h; c) $\mathrm{NaBH}_{4}, \mathrm{MeOH}, 18 \mathrm{~h}(87 \%$, two steps); d) $\mathrm{MsCl}$, $\mathrm{Et}_{3} \mathrm{~N}, 0{ }^{\circ} \mathrm{C}, 3 \mathrm{~h}(85 \%)$; e) $\mathrm{MeNH}_{2}$ (40\% wt.\% solution in water), reflux, $3 \mathrm{~h}(96 \%)$; f) i) $\mathrm{NaH}$, DMSO, $80{ }^{\circ} \mathrm{C}$ for 1h, then 4-chlorobenzotrifluoride, 80 to $100{ }^{\circ} \mathrm{C}, 1 \mathrm{~h}$; ii) $\mathrm{HCl}_{(\mathrm{g})}$, ether $(78 \%)$. 
In summary, $(R)$-fluoxetine hydrochloride $[(R)-\mathbf{1} . \mathrm{HCl}]$ has been synthesized in 6 steps, $50 \%$ overall yield and 99\% ee from benzaldehyde (2). The route described centered around the catalyst $(R, R)$-A developed by Maruoka and coworkers ${ }^{40}$ for enantioselective catalytic allylation reactions (ECA) not only provides one of the shortest route to $(R)-\mathbf{1} . \mathrm{HCl}$ but should be amenable for the preparation of other pharmaceuticals such as atomoxetine and duloxetine.

\section{Experimental}

\section{General}

Reagents and solvents are commercial grade and were used as supplied, except dichloromethane and tetrahydrofuran which were distilled from calcium hydride. Chromatographic separations were performed using 70230 Mesh silica gel. Thin-layer chromatography was carried out on Macherey-Nagel precoated silica plates (0.25 mm layer thickness). IR spectra were obtained on Nicolet Impact 410 FT (film or KBr). ${ }^{1} \mathrm{H}$ NMR and ${ }^{13} \mathrm{C}$ NMR data were recorded on a Varian Gemini 2000 (7.0 T) or Varian Inova $(11.7 \mathrm{~T})$ spectrometer. Chemical shifts are reported in $\delta$ [ppm relative to $\left(\mathrm{CH}_{3}\right)_{4} \mathrm{Si}$ ] for ${ }^{1} \mathrm{H}$ NMR and $\mathrm{CDCl}_{3}$ for ${ }^{13} \mathrm{C}$ NMR. For ${ }^{1} \mathrm{H}$ NMR, the chemical shifts were followed by multiplicity (s, singlet; d, doublet; dd, double dublet; ddd, double double dublet; $t$, triplet; q, quartet; m, multiplet) and coupling constant $J$ reported in Hertz (Hz). High resolution mass spectra (HRMS) were measured on a VG Autospec-Micromass spectrometer. HPLC analysis was performed using Chiralcel OD column; Hex: ${ }^{i} \mathrm{PrOH}, 98: 2$, flow rate $=1 \mathrm{~mL} \mathrm{~min}^{-1}, \lambda_{\text {max. }}=257 \mathrm{~cm}^{-1}$. Optical rotations were measured at $25^{\circ} \mathrm{C}$ with Perkin-Elmer 241 instrument.

\section{(R)-1-Phenyl-but-3-en-1-ol (3) $)^{41,42}$}

Synthesis of chiral bis-Ti(IV) oxide (R,R)-A. To a stirred solution of $\mathrm{TiCl}_{4}(25 \mu \mathrm{L}, 0.23 \mathrm{mmol})$ in $\mathrm{CH}_{2} \mathrm{Cl}_{2}(4.6 \mathrm{~mL})$ was added $\mathrm{Ti}\left(\mathrm{O}^{\mathrm{P}} \mathrm{Pr}\right)_{4}(0.2 \mathrm{~mL}, 0.69 \mathrm{mmol})$ at $0{ }^{\circ} \mathrm{C}$ under argon. The solution was allowed to warm to room temperature. After 1h, silver(I) oxide (107 mg, $0.46 \mathrm{mmol}$ ) was added at room temperature, and the whole mixture was stirred for $5 \mathrm{~h}$ excluding direct light. The mixture was diluted with $\mathrm{CH}_{2} \mathrm{Cl}_{2}(9.2 \mathrm{~mL})$, and treated with $(R)$-BINOL (263 mg, $0.92 \mathrm{mmol}$ ) at room temperature for $2 \mathrm{~h}$ to furnish chiral bis-Ti(IV) oxide $(R, R)$-A.

Asymmetric allylation of benzaldehyde. The in situ generated $(R, R)$-A was cooled to $-15{ }^{\circ} \mathrm{C}$, and treated sequentially with benzaldehyde $(0.48 \mathrm{~mL}, 4.7 \mathrm{mmol})$ and allyl- $n$-tributyltin $(1.8 \mathrm{~mL}, 5.6 \mathrm{mmol})$ at $-15^{\circ} \mathrm{C}$. The mixture was allowed to cool to $-18{ }^{\circ} \mathrm{C}$ (storage in freezer) and stirred for $24 \mathrm{~h}$. The reaction mixture was quenched with saturated aqueous $\mathrm{NaHCO}_{3}$, and extracted with ether. The organic extracts were dried over $\mathrm{MgSO}_{4}$. Evaporation of solvent and purification of the residue by column chromatography on silica gel (hexane: ethyl acetate $=7: 3$ as eluent) gave $(R)-1$ phenyl-but-3-en-1-ol (3) as a colorless oil (90\% yield). The enantiomeric purity of the product was determined to be $>99 \%$ $e e$ by analytic HPLC analysis [Chiralcel OD column;

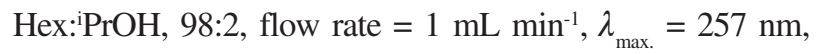
retention time $=11.8 \mathrm{~min}$ for $(S)$-isomer, retention time $=17.2$ $\min$ for $(R)$-isomer] in comparison with the racemic samples. IR (film) $v_{\max } / \mathrm{cm}^{-1}: 3365,3078,3033,2973,2897,1637$, $1637,1448 .{ }^{~} \mathrm{H}$ NMR $\left(300 \mathrm{MHz}, \mathrm{CDCl}_{3}\right) \delta$ 7.24-7.34 (5H, m), 5.72-5.86 $(1 \mathrm{H}, \mathrm{m}), 5.10-5.19(2 \mathrm{H}, \mathrm{m}), 4.69-4.74(1 \mathrm{H}, \mathrm{m}), 2.15-$ $2.53(2 \mathrm{H}, \mathrm{m}), 2.15(1 \mathrm{H}, \mathrm{d}, J 2.6 \mathrm{~Hz}) .{ }^{13} \mathrm{C}$ NMR $(75 \mathrm{MHz}$, $\left.\mathrm{CDCl}_{3}\right) \delta 143.7,134.3,128.2(2 \mathrm{C}), 127.4,125.7(2 \mathrm{C}), 118.2$, 73.2, 43.8. $[\alpha]_{\mathrm{D}}+53^{\circ}\left(c=1.1, \mathrm{C}_{6} \mathrm{H}_{6}\right)$, lit. $^{42}[\alpha]_{\mathrm{D}}-50.5^{\circ}(c=1.1$, $\left.\mathrm{C}_{6} \mathrm{H}_{6}\right)$ for $(S)$-isomer in $96 \% e e$.

\section{(R)-1-Phenyl-1,3-propanediol (4) $)^{15,32}$}

To a stirred solution of ( $R$ )-1-phenyl-but-3-en-1-ol (3) (550 $\mathrm{mg}, 3.71 \mathrm{mmol})$ in a mixture of ethyl ether $(12 \mathrm{~mL})$ and water $(12 \mathrm{~mL})$ was added $\mathrm{OsO}_{4}(28 \mathrm{mg}, 0.11 \mathrm{mmol})$ and the mixture was stirred for $10 \mathrm{~min}$ at room temperature. Powdered $\mathrm{NaIO}_{4}$ $(1.75 \mathrm{~g}, 8.16 \mathrm{mmol})$ was then added over a $40 \mathrm{~min}$ period and stirring was continued for $2 \mathrm{~h}$ at room temperature. The mixture was poured into ethyl ether $(200 \mathrm{~mL})$ and aqueous layer was extracted with ethyl ether $(3 \times 50 \mathrm{~mL})$. The organic layers were combined and dried with $\mathrm{MgSO}_{4}$ and filtered. The crude hydroxy aldehyde derivative from $\mathbf{3}$ was used immediately for the preparation of the diol 4 . To crude hydroxy aldehyde dissolved in THF ( $23 \mathrm{~mL}$ ) was added $\mathrm{NaBH}_{4}(532 \mathrm{mg}, 11.13$ $\mathrm{mmol}$ ) at $0{ }^{\circ} \mathrm{C}$. After $12 \mathrm{~h}$, the reaction mixture was then treated with $\mathrm{NaHCO}_{3}$ aqueous saturated solution $(100 \mathrm{~mL})$, and extracted with ethyl ether $(3 \times 100 \mathrm{~mL})$. The organic layers were combined and dried with $\mathrm{MgSO}_{4}$ and filtered. Purification of the residue by chromatography on silica gel (dichloromethane: methanol $=9: 1$ as eluent) gave $(R)-1$ phenyl-1,3-propanediol (4) as an oil (491 mg, 87\% yield). IR (film) $v_{\max } / \mathrm{cm}^{-1}: 3350,3033,2942,2882,1493,1422,1342$, $1278,1044 .{ }^{~} \mathrm{H} \mathrm{NMR}\left(300 \mathrm{MHz}, \mathrm{CDCl}_{3}\right) \delta$ 7.27-7.37 (5H, m), $4.96(1 \mathrm{H}, \mathrm{dd}, J 8.8$ and $4.0 \mathrm{~Hz}), 3.83-3.87(2 \mathrm{H}, \mathrm{t}, J 7.5 \mathrm{~Hz})$, $2.70(2 \mathrm{H}, \mathrm{br} \mathrm{s}), 1.84-2.08(2 \mathrm{H}, \mathrm{m}) .{ }^{13} \mathrm{CNMR}\left(125 \mathrm{MHz}, \mathrm{CDCl}_{3}\right)$ $\delta 144.3,128.5$ (2C), 127.6, $125.6(2 \mathrm{C}), 74.4,61.5,40.5 .[\alpha]_{\mathrm{D}}$ $+66^{\circ}\left(c=2.4, \mathrm{CH}_{2} \mathrm{Cl}_{2}\right)$, lit. $^{32}[\alpha]_{\mathrm{D}}+65^{\circ}\left(c=2.4, \mathrm{CH}_{2} \mathrm{Cl}_{2}\right)$.

\section{(R)-N-Methyl-1-phenyl-3-amino-1-propanol (6) ${ }^{15}$}

To a solution of (R)-1-phenyl-1,3-propanediol (4) (271 
$\mathrm{mg}, 1.78 \mathrm{mmol})$ and triethylamine $(260 \mathrm{mg}, 2.56 \mathrm{mmol})$ in dichloromethane $(9 \mathrm{~mL})$ was added dropwise $\mathrm{MsCl}(145$ $\mu \mathrm{L}, 1.87 \mathrm{mmol}$ ) under nitrogen at $-10^{\circ} \mathrm{C}$, then the mixture was heated to $0{ }^{\circ} \mathrm{C}$. After stirring at $0{ }^{\circ} \mathrm{C}$ for $3 \mathrm{~h}$, the mixture was poured into ice water $(10 \mathrm{~mL})$, washed with $20 \% \mathrm{H}_{2} \mathrm{SO}_{4}$ ( $7 \mathrm{~mL}, \mathrm{v} / \mathrm{v})$, saturated aqueous $\mathrm{NaHCO}_{3}(10 \mathrm{~mL})$, and brine, and dried over magnesium sulfate. The solvent was evaporated and the crude reaction mixture was diluted with methylamine $(10 \mathrm{~mL}, 40 \%$ in water $)$ in THF $(10 \mathrm{~mL})$ and then heated at $65^{\circ} \mathrm{C}$ for $3 \mathrm{~h}$. After cooling, the solution was diluted with ether, washed with saturated aqueous sodium bicarbonate and brine, and dried with anhydrous potassium carbonate. Concentration to dryness provides the title compound 6 (476 mg, 81\%, 2 steps). IR (film) $v_{\max } / \mathrm{cm}^{-1}: 3350,3056,3026,2965,2867,2807,1497$, 1448, 1388, 1259, 1063, 1033. ${ }^{1} \mathrm{H} \mathrm{NMR}\left(300 \mathrm{MHz} \mathrm{CDCl}_{3}\right)$ $\delta 7.22-7.34$ (5H, m), 4.92 (1H, dd, $J 8.5$ and $3.3 \mathrm{~Hz}), 3.70-$ 3.80 (1H, br s), 2.83-2.91 (2H, m), 2.44 (3H, s), 1.78-1.96 $(3 \mathrm{H}, \mathrm{m}) .{ }^{13} \mathrm{C}$ NMR $\left(75 \mathrm{MHz}, \mathrm{CDCl}_{3}\right) \delta 143.7,134.3$, 128.2(2C), 127.4, 125.7(2C), 118.2, 73.3, 43.8. $[\alpha]_{\mathrm{D}}+36^{\circ}$ $\left(c=1.0, \mathrm{CH}_{2} \mathrm{Cl}_{2}\right)$, lit. ${ }^{33}[\alpha]_{\mathrm{D}}-33.5^{\circ}\left(c=1.0, \mathrm{CH}_{2} \mathrm{Cl}_{2}\right)$ for $(S)$ isomer in $95 \%$ ee.

\section{(R)-Fluoxetine hydrochloride $[(\mathrm{R})-\mathrm{I} . \mathrm{HCl}]^{15,30}$}

A solution of (R)- $N$-methyl-3-phenyl-3-hydroxypropylamine (6) $(123 \mathrm{mg}, 0.75 \mathrm{mmol})$ in DMSO $(7 \mathrm{~mL})$ was added sodium hydride (22 $\mathrm{mg}, 0.89 \mathrm{mmol})$ with cooling. The mixture was heated at $80{ }^{\circ} \mathrm{C}$ for $1 \mathrm{~h}$. $p$-Chlorobenzotrifluoride was added and the mixture was heated for $1 \mathrm{~h}$ at 80 to $100{ }^{\circ} \mathrm{C}$ and cooled. Extractive isolation with ethyl acetate $(3 \times 50 \mathrm{~mL})$ afforded the free base form of $\mathbf{1}$ which after concentration, pale yellow oil was obtained. The oil was dissolved in ether and hydrogen chloride gas was bubbled through the solution until white precipitate was formed. The title compound $(R)-\mathbf{1}$. $\mathrm{HCl}$ was colleted as a white solid (200 mg, 78\%). IR (KBr) $v_{\max } / \mathrm{cm}^{-1}$ : 2961, 2935, 2799, 2735, 2448, 2448, 1614, 1520, 1324, 1233, 1169, 1101, 1063. ${ }^{1} \mathrm{H}$ NMR $\left(300 \mathrm{MHz}, \mathrm{CDCl}_{3}\right) \delta$ $9.60(2 \mathrm{H}$, br s), $7.41(2 \mathrm{H}, \mathrm{d}, J 8.8 \mathrm{~Hz}), 7.25-7.34(5 \mathrm{H}, \mathrm{m})$, $6.89(2 \mathrm{H}, \mathrm{d}, J 8.8 \mathrm{~Hz}), 4.96(1 \mathrm{H}, \mathrm{dd}, J 8.0$ and $4.8 \mathrm{~Hz}), 3.04$ $3.17(2 \mathrm{H}, \mathrm{m}), 2.62(3 \mathrm{H}, \mathrm{s}), 2.39-2.58(2 \mathrm{H}, \mathrm{m}) .{ }^{13} \mathrm{C} \mathrm{NMR}$ $\left(125 \mathrm{MHz} \mathrm{CDCl}_{3}\right) \delta 159.6,139.0,129.0,128.4(2 \mathrm{C})$, 126.8(2C), 125.7, 124.7(2C), 123.3(2C), 115.8, 76.9, 46.1, 34.5, 33.0. $[\alpha]_{\mathrm{D}}-14^{\circ}\left(c=1, \mathrm{CHCl}_{3}\right), \operatorname{lit}^{23}[\alpha]_{\mathrm{D}}-13.8^{\circ}(c=1$, $\left.\mathrm{CHCl}_{3}\right)$.

\section{Acknowledgments}

The authors would like to thank FAPESP (Fundação de Amparo a Pesquisa no Estado de São Paulo) for financial support and fellowships (A.F. and A.A.M.L.) and CNPq (Conselho Nacional de Desenvolvimento Científico e Tecnológico) for research fellowship (R.A.P.).

\section{References}

1. Romeiro, L. A. S.; Fraga, C. A. M.; Barreiro, E. J.; Quim. Nova 2003, 26, 347

2. Lapis, A. A. M.; de Fátima, A.; Martins, J. E. D.; Costa, V. E. U.; Pilli, R. A.; Tetrahedron Lett. 2005, 46, 495.

3. Robertson, D.A.; Krushinski, J.H.; Fuller, R.W.; Leander, J. D.; J. Med. Chem. 1988, 31, 1412.

4. Robertson, D. W.; Jones, N. D.; Swartzendruber, J. K.; Yang, K. S.; Wong, D. T.; J. Med. Chem. 1988, 31, 185.

5. Murphy, D.L.; Mueller, E.A.; Garrick, N.A.; Aulakh, C.S.; J. Clin. Psychiatry 1986, 47, 9.

6. Wilde, M. I.; Benfield, P.; Pharmacoeconomics 1998, 13, 543.

7. Montgomery, S. A.; Int. Clin. Psychopharmacol. 1998, 13, S49.

8. Garrison, G. D.; Levin, G. M.; Ann. Pharmacother. 2000, 34, 10 .

9. Bianchi, M.; Sacerdote, P.; Panerai, A. E.; Eur. J. Pharmacol. 1994, 263, 81 .

10. Bianchi, M.; Rossoni, G.; Sacerdote, P.; Panerai, A. E.; Berti, E.; Inflamm. Res. 1995, 44, 466.

11. Sawynok, J.; Esser, M. J.; Reid, A. R.; Pain 1999, 82, 149.

12. Abdel-Salam, O. M. E.; Baiuomy, A. R.; Arbid, M. S.; Pharmacol. Res. 2004, 49, 119.

13. Some recent processes for preparing fluoxetine or intermediates for its total synthesis: Wallace, H. J.; Hugh, S. C.; Roger, J. A.; $A U$ Patent 4579399, 2000; Wallace, H. J.; Roger, J. A.; WO Patent 0007976, 2000; Xin, C.; Jingen, D.; Tongfei, W.; CN Patent 1294120, 2001; Wallace, H. J.; Roger, J. A.; Hugh, S. C.; US Patent 6028224, 2000; Bhasker, K. G.; Vijaya, R. K.; Venkateswara, R. M.; GB Patent 2387597, 2003.

14. Pandey, R. K.; Fernades, R. A.; Kumar, P.; Tetrahedron Lett. 2002, 43, 4425 .

15. Gao, Y.; Sharpless, K. B.; J. Org. Chem. 1988, 53, 4081.

16. Kakei, H.; Nemoto, T.; Ohshima, T.; Shibasaki, M.; Angew. Chem. Int. Ed. 2004, 43, 317.

17. Mitchell, D.; Koenig, T. M.; Syn. Comm. 1995, 25, 1231.

18. Hilbon, J. W.; Lu, Z. H.; Jurgens, A. R.; Fang, Q. K.; Byers, P.; Wald, S. A.; Senanayake, C. H.; Tetrahedron Lett. 2001, 42, 8919

19. Devocelle, M.; Agbossou, F.; Mortreux, A.; Synlett 1997, 1306.

20. Sakuraba, S.; Achiwa, K.; Chem. Pharm. Bull. 1995, 43, 748.

21. Sakuraba, S.; Achiwa, K.; Synlett 1991, 689.

22. Srebnik, M.; Ramachandran, P.V.; Brown, H.C.; J. Org. Chem. 1988, 59, 2916

23. Corey, E. J.; Reichard, G. A.; Tetrahedron Lett. 1989, 30, 5207 
24. Gu, J.-X.; Li, Z.-Y.; Lin, G.-Q.; Tetrahedron 1993, 49, 5805.

25. Boaz, N. W.; J. Org. Chem. 1992, 57, 4289.

26. Schneider, M.P.; Goergens, U.; Tetrahedron: Asymmetry 1992, 3,525

27. Kumar, A.; Ner, D.H.; Dike, S. Y.; Tetrahedron Lett. 1991, 32, 1901.

28. Chenevert, R.; Fortier, G.; Chem. Lett. 1991, 1603.

29. Devine, P. N.; Heid, R. M.; Tschaen Jr., D. M.; Tetrahedron 1997, 53, 6739.

30. Miles, W. H.; Fialcowitz, E. J.; Halstead, E. S.; Tetrahedron 2001, 57, 9925.

31. Bracher, F.; Litz, T.; Bioorg. Med. Chem. 1996, 4, 877.

32. Master, H. E.; Newadkar, R. V.; Rane, R. A.; Kumar, A.; Tetrahedron Lett. 1996, 37, 9253.

33. Ali, I. S.; Sudalai, A.; Tetraheron Lett. 2002, 43, 5435.

34. Koenig, T.M.; Mitchell, D.; Tetrahedron Lett. 1994, 35, 1339.

35. Trost, B.; Proc. Natl. Acad. Sci. USA 2004, 101, 5348.
36. Correa, I. R.; Pilli, R. A.; Quim. Nova 2003, 26, 531.

37. Denmark, S. E.; Fu, J.; Chem. Rev. 2003, 103, 2763.

38. de Fátima, A.; Pilli, R. A.; Arkivoc 2003, 10, 118.

39. de Fátima, A.; Pilli, R. A.; Tetrahedron Lett. 2003, 44, 8721.

40. de Fátima, A.; Kohn, L. K.; Antônio, M. A.; de Carvalho, J. E.; Pilli, R. A.; Bioorg. Med. Chem. 2004, 12, 5437.

41. Hanawa, H.; Hashimoto, T.; Maruoka, K.; J. Am. Chem. Soc. 2003, 125, 1708.

42. Yanagisawa, A.; Nakashima, H.; Nakatsuka, Y.; Ishiba, A.; Yamamoto, H.; Bull. Chem. Soc. Jpn. 2001, 74, 1129.

43. Pappo, R.; Jr. Allen, D. S.; Lemieux, R. U.; Johnson, W. S.; J. Org. Chem. 1956, 21, 478.

Received: November 6, 2004 Published on the web: April 12, 2005

FAPESP helped in meeting the publication costs of this article. 